\title{
Structural and Floristic Pattern in a Disturbed Mangrove Tropical Swamp Forest: A Case Study from the Langkawi UNESCO Global Geopark Forest, Peninsular Malaysia \\ (Struktur dan Corak Flora di Hutan Paya Bakau Tropika: Suatu Kajian Kes dari Global Geopark Forest UNESCO Langkawi, Semenanjung Malaysia)
}

\author{
WAN NORILANI WAN ISMAIL*, WAN JULIANA WAN AHMAD, MUHAMMAD RAZALI SALAM \& A. LATIFF
}

\section{ABSTRACT}

Forest structure, diversity and above-ground biomass assessment are important to understand the structural and floristic dynamics of a mangrove forest ecosystem. Our study provides valuable comparative analysis between two areas of disturbed mangroves at Kisap Forest Reserve, Langkawi Island. The two study sites were swamp forest at C5 which was disrupted by harvesting activities for charcoal production and C7 was disturbed by lightning strikes. A total of 1,217 and 390 trees measuring $1 \mathrm{~cm}$ diameter and above were enumerated in 0.25 ha plots at both sites. Seven mangrove plant species in $C 5$ and eight in $C 7$ were recorded. Ceriops tagal and Rhizophora apiculata were the most prominent species in the $C 5$ and C7, respectively, whereby the Rhizophoraceae was the densest family at both sites. The major contributor of total basal area at C5 and C7 were C. tagal $\left(5.02 \mathrm{~m}^{2} / \mathrm{ha}\right)$ and R. apiculata $\left(11.14 \mathrm{~m}^{2} / \mathrm{ha}\right)$. Similarly, C. tagal (22.41 t/ ha) and $\mathrm{R}$. apiculata $(111.75 \mathrm{t} / \mathrm{ha}$ ) also contributed the highest biomass in $\mathrm{C} 5$ and $\mathrm{C} 7$, respectively. Diversity and species richness were higher at $C 7 H^{\prime}=1.22 ; R^{\prime}=1.17$ compared to $C 5 H^{\prime}=0.76 ; R^{\prime}=0.85$ and low evenness at both sites. High similarity was indicated between the two sites by $93 \%$. The distribution of individuals in $C 7$ was homogenous than that of $C 5$, which had more saplings. In conclusion, anthropogenic activities resulted in lower productivity of forest compared to natural disturbances.

Keywords: Biomass; disturbance; diversity; forest structure; mangrove plants

\section{ABSTRAK}

Penilaian struktur hutan, kepelbagaian dan biojisim atas tanah adalah penting dalam memahami struktur dan kedinamikan flora sesuatu ekosistem hutan paya bakau. Kajian ini menyediakan analisis perbandingan antara dua kawasan terganggu di Hutan Simpan Kisap, Pulau Langkawi. Dua kawasan kajian tersebut adalah hutan paya bakau di C5 yang terganggu oleh aktiviti penghasilan kayu arang, manakala, C7 terganggu oleh panahan petir. Sejumlah 1,217 dan 390 pokok berdiameter $1 \mathrm{~cm}$ dan ke atas telah diukur di dalam plot bersaiz 0.25 ha di kedua-dua kawasan. Tujuh spesies pokok bakau dalam C5 dan lapan spesies dalam C7 telah direkod. Ceriops tagal dan Rhizophora apiculata merupakan spesies yang paling menonjol masing-masing dalam C5 dan C7 dengan Rhizophoraceae adalah famili yang paling padat di kedua-dua kawasan. Penyumbang luas pangkal terbesar di C5 dan C7 adalah C. tagal $\left(5.02 \mathrm{~m}^{2} / \mathrm{ha}\right)$ dan R. apiculata $\left(11.14 \mathrm{~m}^{2} / \mathrm{ha}\right)$. C. tagal $(22.41 \mathrm{t} / \mathrm{ha})$ dan R. apiculata (111.75 t/ha) juga menyumbang biojisim terbanyak masing-masing di C5 dan C7. Kepelbagaian dan kekayaan spesies adalah lebih tinggi di $C 7 H^{\prime}=1.22 ; R^{\prime}=1.17$ berbanding di $C 5 H^{\prime}=$ $0.76 ; R^{\prime}=0.85$ dan keseragaman yang rendah di kedua-dua kawasan. Indeks kesamaan komuniti antara dua kawasan kajian ini adalah tinggi iaitu 93\%. Taburan individu di C7 adalah lebih homogen berbanding di C5 yang mempunyai lebih banyak anak pokok. Kesimpulannya, gangguan antropogenik menyebabkan produktiviti hutan yang lebih rendah berbanding kesan daripada gangguan semula jadi.

Kata kunci: Biojisim; gangguan; kepelbagaian; struktur hutan; tumbuhan bakau

\section{INTRODUCTION}

Langkawi UNESCO Global Geopark is one of the designated conservation areas for sustainable development with the emphasis on the balance between heritage conservation and sustainable use of resources. The Kilim-Kisap Geopark Forest is one of the largest mangrove swamp forests that grow on shallow limestone substratum. The conservation of this unique mangrove habitat has provided an excellent opportunity to investigate the pattern of forest structure and floristic variation due to different sources of disturbance.

Mangroves are known to have undergone adaptations and have very high resistance to harsh environmental conditions, i.e. strong wind, high temperature and high salinity (Clough 2013). They are, however, very sensitive to disturbances, either natural or artificial. These interferences have caused death of trees and resulting in 
formation of canopy gaps. Examples of disturbances that often associated with this phenomenon are hurricanes, oil spills, lightning strikes, pest and human exploitation (Aldrie \& Latiff 2006; Farnsworth \& Ellison 1997; Feller \& McKee 1999; Garrity et al. 1994; Imbert et al. 2000; Sherman et al. 2000). Those disturbances, especially anthropogenically intruded not only affected mangrove ecosystems but also caused a major impact on shorebirds and water birds abundance. Thus, influenced their foraging behavior (Rosli \& Nor Atiqah 2017).

Estimates of world-wide mangrove extension is $152,000 \mathrm{~km}^{2}$ (Spalding 2010), and South-east Asia has the largest area of mangroves, extending over 6.8 million ha or $34-42 \%$ of the world's mangroves (Giesen et al. 2006). Malaysia represents $11.7 \%$ from the total Southeast Asia's (second largest after Indonesia). Mangrove forests in Peninsular Malaysia, covers an area of 105,693 ha (FDPM 2014). Langkawi Island, Kedah is covered by about 3,378 ha and the largest area is at the Kisap Forest Reserve with 1,336 ha. Langkawi mangrove forests have the richest mangrove plant communities in Malaysia (Wan Juliana et al. 2014).

The total number of true mangrove plant species in the world is about 70 and they belong to 17 families. Out of the 70,51 species are present in the South Asian mangrove wetlands (Duke 1992; Polidoro et al. 2010) and 38 species are in Malaysia (Japar Sidik 1994). The mangrove species list by Japar Sidik (1994) stated there were 104 species recorded throughout Malaysia. Recently, Wan Juliana et al. (2014) made an updated list of 119 species of mangrove plants, including 41 exclusives, 65 non-exclusives and 13 associate mangrove species recorded in Pulau Langkawi. The findings not only added the number of mangrove species recorded in Pulau Langkawi, but it proved that Pulau Langkawi has the most mangrove species in Malaysia.

As Langkawi Island has an outstanding geological history and landscape features from its natural settings, it attracts both tourists and researchers. The endorsement of UNESCO Langkawi Global Geopark in June 2007and the fact that the island is a free duty zone has made Langkawi even more hectic with rapid socio-economic developments. Socio-economic developments seem to be the main threat to the mangrove forests in Langkawi Island, as these activities involved the conversion of large mangrove areas to other land-use. The conversion of the land caused disruption to forests sustainability and led to degradation in forest quality and ecosystem functions (Clough 2013). They may also have resulted in the loss of a huge number of individuals of mangrove species (Aldrie \& Latiff 2006).

Studies on species composition, community structure and biomass of forests are important to determine and understand the condition, function and productivity (carbon sequestration) of a forest. Meanwhile, analysis of biomass within communities in a given time is essential to have a clear vision in understanding the dynamic of organic cycles in the mangrove forests (Soares \& Schaeffer-Novelli 2005). Furthermore, the estimation of above-ground biomass is widely used in the implementation of a better forest management from the understanding of their characteristic such as, age of the stand, history, structure difference and climate influence (Hase et al. 1985; Komiyama et al. 1988; Lugo \& Snedaker 1974; Rodin et al. 1967). For instance, a study by Rasheed et al. (2013) indicated that Avicennia marina is better adapted for the projected climate change than Bruguiera parviflora as the carbon sequestration in $A$. marina had fewer responses to tidal flooding than those in B. parviflora.

Our study is a comparative analysis between two types of disturbed mangrove forests at Kisap Forest Reserve, Langkawi Island. We aimed to determine the forest structure, forest diversity and estimate the aboveground biomass of these sites. Data gathered would assist in the prioritization of biosites within the Langkawi UNESCO Global Geopark.

\section{MATERIALS AND METHODS}

\section{STUDY SITES}

The study was carried out at two selected locations in Kisap Forest Reserve, Langkawi Island, i.e. compartment 5 (C5) (06 22'53.3" N, 99 53'34.5" E) and compartment 7 (C7) $\left(06^{\circ} 23^{\prime} 26.5^{\prime \prime} \mathrm{N}, 99^{\circ} 51^{\prime} 49.3^{\prime \prime} \mathrm{E}\right)$ (Figure 1). The C5 was disturbed by human activities (harvested for wood charcoal from 2003-2005, while C7 was disturbed by lightning strikes in 2009 . A plot of $50 \mathrm{~m} \times 50 \mathrm{~m}$ in each compartment was established in gap phases that resulted from those disturbances. All mangrove trees with diameter at breast height $(\mathrm{DBH}) \geq 1 \mathrm{~cm}$ were measured and identified.

\section{DATA ANALYSIS}

Dominance of a species was determined by the Importance Index Value (IVi) (Brower et al. 1997). Abundance parameters, includes density, basal area and importance value index for each mangrove tree species, along with the DBH size class distribution were calculated and analysed for comparison and determination of forest stand structure (Curtis \& Macintosh 1951).

The Shannon Diversity Index (H'), Margalef Richness Index (R) was used to determine species diversity. These values were calculated using Paleontological Statistics Software (PAST) (2001) (Hammer et al. 2001). The Sørensen Coefficient Value (CCs) was used to measure similarity of species among study sites (Magurran 1988). The CCs formula adapted in this study was from Brower and Zar (1977).

The above-ground biomass (AGB) of mangrove species was estimated using the formula introduced by Komiyama et al. (2005). These allometric equations were based on the DBH parameter. 


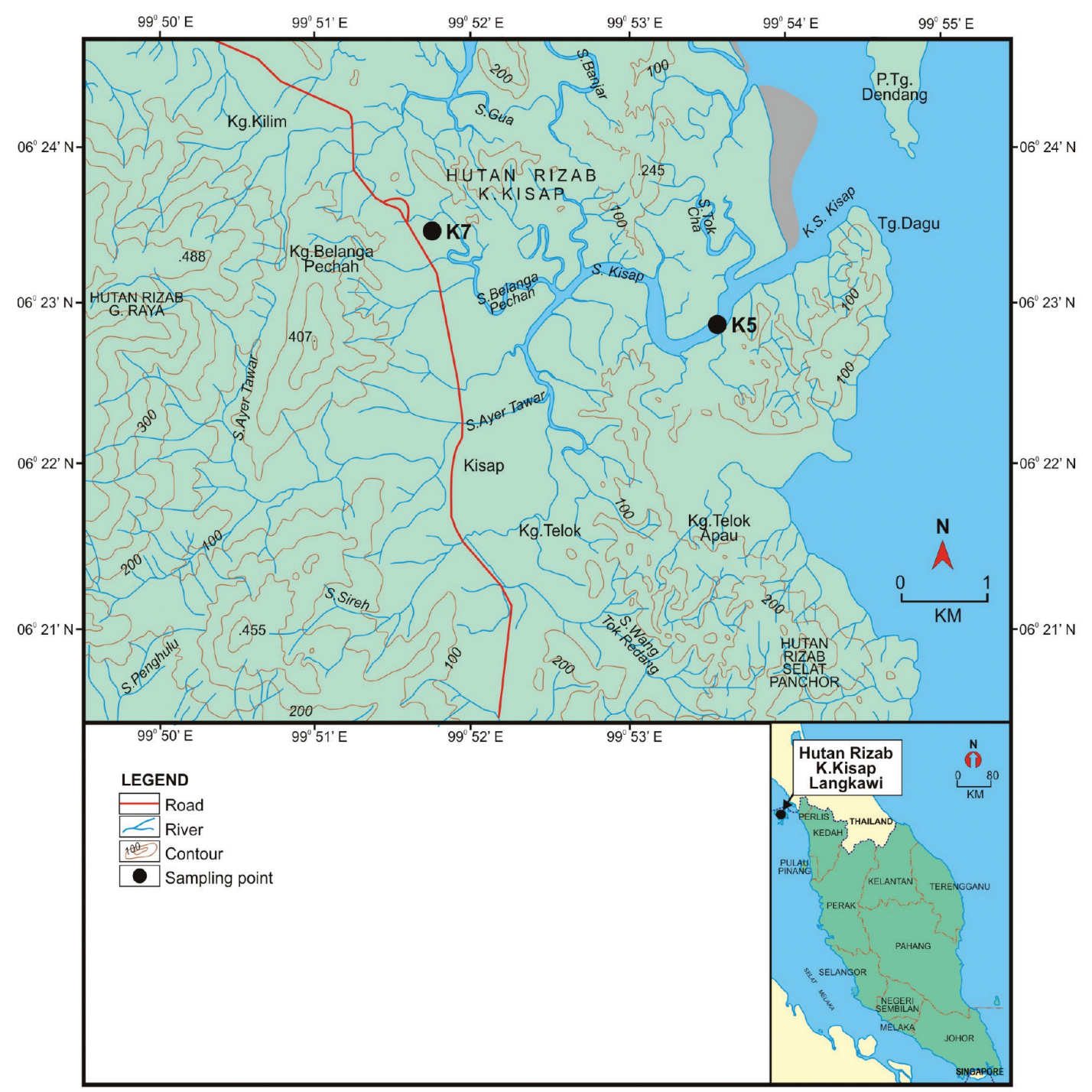

FIGURE 1. Map of Langkawi Island showing the study sites at Kisap Forest Reserve, Langkawi Island, Peninsular Malaysia

\section{RESULTS AND DISCUSSION}

\section{FOREST STAND STRUCTURE}

A total of 1217 individual trees were recorded in C5 of the Kisap Forest Reserve, which comprises 7 species and 5 genera from 3 families. There were Ceriops tagal, Rhizophora apiculata, R. mucronata, Bruguiera parviflora and B. gymnorrhiza (Rhizophoraceae), Xylocarpus granatum (Meliaceae) and Avicennia officinalis (Avicenniaceae). In C7, less number of individuals was recorded at 390 individual trees with 8 species, 5 genera from 3 families. Species occurring in C7 are similar to those in C5 except for an additional of X. moluccensis at C7. The largest family in both sites was Rhizophoraceae, represented by 5 species (Table 1). Our results indicated that both sites had comparable species richness regardless of the different types of disturbances. However, the number of tree individuals was strikingly different between the two sites $(p<0.05)$. The site that was disturbed by human activities had greater number of mangrove individuals compared to the site that was disturbed by lightning strikes.

\section{BUNDANCE}

Density of trees enumerated at C5 was 4868 trees/ha, whilst that in C7 was lower at 1,560 trees/ha. Mangrove species with the highest density was $C$. tagal with a density of 3,420 trees/ha at C5 and R. apiculata with 800 trees/ha at $\mathrm{C} 7$. Our results clearly showed that the differences in the total species density between the two sites was due to the high abundance of small size tree stems in C5 compared to C7 (Figure 2). Higher total species density in C5 was also related to the smaller median stem diameter size compared to larger median stem diameter size in C7.

The C5 area was mainly covered by Rhizophoraceae with a basal area of $7.72 \mathrm{~m}^{2} /$ ha out of the total basal area of $7.77 \mathrm{~m}^{2} /$ ha. The $\mathrm{C} 7$, showed a far higher total basal area than that of $\mathrm{C} 5$, with $18.18 \mathrm{~m}^{2} /$ ha. Rhizophoraceae was 
TABLE 1. Species composition in Compartment 5 and Compartment 7 at Kisap Forest Reserve,

Langkawi Island, Peninsular Malaysia

\begin{tabular}{cclcc}
\hline \multirow{2}{*}{ No. } & \multirow{2}{*}{ Family } & Species & \multicolumn{2}{c}{ No. of individuals } \\
\cline { 3 - 4 } & & & C5 & C7 \\
\hline 1 & Avicenniaceae & Avicennia officinalis L. & 2 & 1 \\
2 & Rhizophoraceae & Bruguiera parviflora (Roxb.) Wight \& Arn. ex Griff. & 11 & 20 \\
3 & & Bruguiera gymnorrhiza (L.) Lam. ex Savigny & 1 & 4 \\
4 & & Ceriops tagal (Pers.) C.B. Rob. & 855 & 129 \\
5 & & Rhizophora apiculata Blume & 317 & 200 \\
6 & Meliaceae & Rhizophora mucronata Lam. & 6 & 12 \\
7 & & Xylocarpus granatum J. König & 25 & 22 \\
8 & Total & & 1,217 & 2 \\
& & &
\end{tabular}

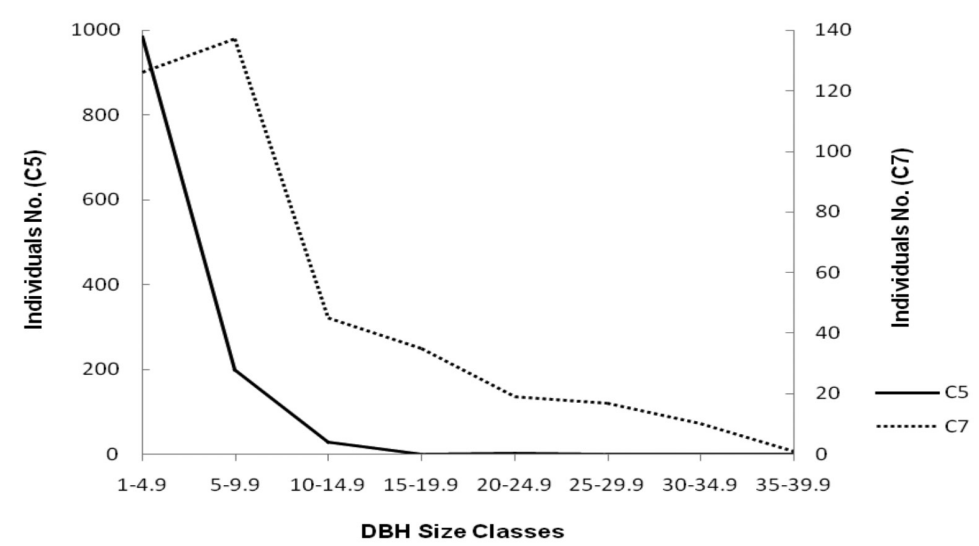

FIGURE 2. The DBH class distribution of trees for Compartment 5 and Compartment 7 at Kisap Forest Reserve, Langkawi Island, Peninsular Malaysia

also the main contributor to the total basal area by $98.42 \%$ or $17.90 \mathrm{~m}^{2} /$ ha. Each compartment, however, was mainly dominated by different species, i.e. C. tagal $\left(5.02 \mathrm{~m}^{2} / \mathrm{ha}\right)$ for C5 and R. apiculata $\left(11.14 \mathrm{~m}^{2} / \mathrm{ha}\right.$ ) for C7 (Table 2). The Importance Value Index of each species (IVi) indicates species dominance. According to Curtis and Macintosh (1951), IVi more than 10 indicates the species has absolute dominance in a forest community. The $C$. tagal was the most dominant species for C5, followed by $R$. apiculata. As for C7, R. apiculata was the most dominant mangrove species, followed by $C$. tagal (Table 2). The result from this study confirmed what was claimed by Wan Juliana et al. (2014) that Rhizophoraceae was distributed all over Peninsular Malaysia with $R$. apiculata dominating almost all areas. However, our study implied that, once a mangrove habitat is disturbed, tree species dominance or in other words, community structure will change.

\section{RANK-ABUNDANCE CURVE}

Rank-Abundance Curve (RAC) is used to display the pattern of species distribution of a community through species richness and evenness. Species richness can be seen as the number of different species on the graph (number of species ranked) while, species evenness is reflected in the slope of the line that fits the graph. Essentially, a community with perfect evenness would be flat instead of declining, indicating that every species has the similar abundance. The one with such striking disparities in abundance among species is said to have low evenness (Magurran 2004).

Rank abundance curve of C5 and C7 on species abundance data showed a steep gradient indicated low evenness as the high-ranking species have much higher abundances than the low-ranking species (Figure 3). Mangrove vegetation is usually dominated by one species (Tomlinson 1986) and this is true for both sites. This pattern of species distribution where one species is highly abundant, and the rest are moderate to relatively rare can be found in other communities (Mc Gill et al. 2007). At site C5,C.tagal dominated the vegetation composition and $R$. apiculata dominated at site C7. Both curves are steep; subsequent species are rapidly reduced in abundance and very few species numerically rare, two species had two and one individual each at both sites. Both sites showing similar geometric series distribution pattern, although it is more pronounced in plot C5 (Chi-squared value $=255.9)$ compared to that of $\mathrm{C} 7$ (Chi-squared value $=28.43$ ). This result confirms the species dominance in mangrove ecosystems. For a depauperated forest communities such as mangrove where vegetation species richness was represented by salt-tolerant species, certain species may become highly abundant (Macnae 1968), utilizing rich 
TABLE 2. Basal area, density, frequency, and importance value index of all species in Compartment 5 and Compartment 7 at Kisap Forest Reserve, Langkawi Island, Peninsular Malaysia

\begin{tabular}{|c|c|c|c|c|c|c|c|c|}
\hline \multirow[t]{2}{*}{ Species } & \multicolumn{2}{|c|}{ Basal Area $\left(\mathrm{m}^{2} / \mathrm{ha}\right)$} & \multicolumn{2}{|c|}{ Density (trees/ha) } & \multicolumn{2}{|c|}{$\begin{array}{l}\text { Frequency } \\
\qquad \%)\end{array}$} & \multicolumn{2}{|c|}{$\begin{array}{c}\text { Importance Value } \\
(\%)\end{array}$} \\
\hline & $\mathrm{C} 5$ & $\mathrm{C} 7$ & $\mathrm{C} 5$ & $\mathrm{C} 7$ & $\mathrm{C} 5$ & $\mathrm{C} 7$ & $\mathrm{C} 5$ & $\mathrm{C} 7$ \\
\hline Ceriops tagal & 5.022 & 2.256 & 3420 & 516 & 100 & 100 & 52.38 & 21.22 \\
\hline Rhizophora apiculata & 2.294 & 11.135 & 1268 & 800 & 100 & 100 & 25.94 & 43.57 \\
\hline Bruguiera parviflora & 0.348 & 3.246 & 44 & 80 & 75 & 100 & 7.35 & 13.72 \\
\hline Rhizophora mucronata & 0.032 & 0.937 & 24 & 48 & 25 & 50 & 2.16 & 5.77 \\
\hline Bruguiera gymnorrhiza & 0.019 & 0.323 & 4 & 16 & 25 & 25 & 1.96 & 2.45 \\
\hline Xylocarpus granatum & 0.047 & 0.159 & 100 & 88 & 75 & 100 & 6.44 & 8.23 \\
\hline Xylocarpus moluccensis & & 0.124 & & 8 & & 50 & & 3.43 \\
\hline Avicennia officinalis & 0.005 & 0.004 & 8 & 4 & 50 & 25 & 3.78 & 1.61 \\
\hline & 7.767 & 18.184 & 4868 & 1560 & 450 & 550 & 100 & 100 \\
\hline
\end{tabular}

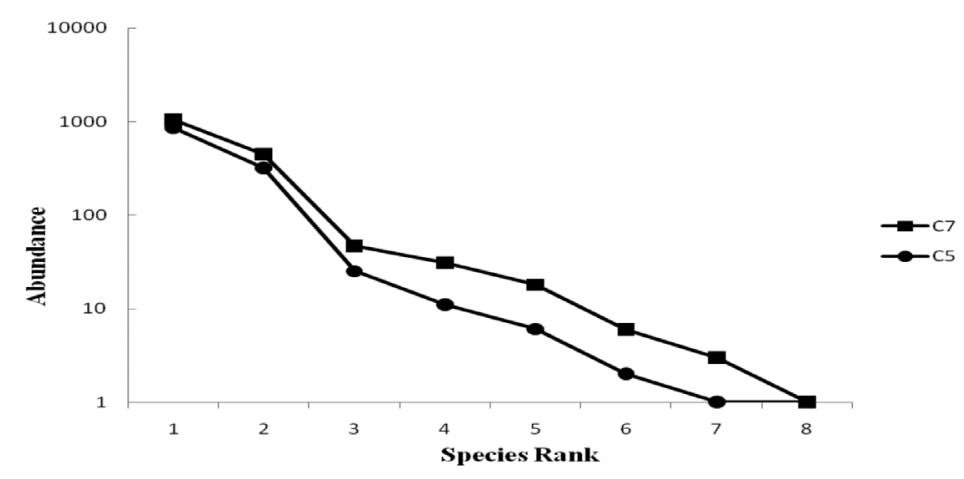

FIGURE 3. Rank-Abundance Curve for Compartments 5 and 7 at Kisap Forest Reserve Langkawi Island, Peninsular Malaysia

natural resources locally available and dominating in density and biomass.

\section{DIVERSITY}

Species Diversity Shannon Diversity Index (H') showed C7 had a higher value of $H^{\prime}=1.219$ compared to $H^{\prime}=0.763$ at $\mathrm{C} 5$. The value stated for $\mathrm{C} 7$ is common to the $\mathrm{H}^{\prime}$ value at Forest Reserve Ayer Hangat $(1.20 \pm 0.67)$ and Forest

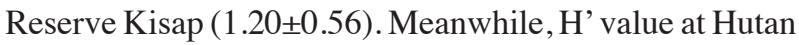
Simpan Matang from the same study showed a value of $(0.82 \pm 0.74)$ which is similar to those in C5 from this study (Norhayati et al. 2005). Comparatively, a study in Trang Province, Southern Thailand recorded H' value ranges 1.4 to 1.99 in its four study sites (Sudtongkong \& Webb 2008). Bahile Mangrove Forest, Palawan, Philippines showed a very low H' value of 0.99 . This could be attributed to the dominance of species, especially from Rhizophoraceae (Abino et al. 2014). Tanjung Puting National Park, Indonesia recorded the highest diversity of all, with $\mathrm{H}^{\prime}$ value of 3.29 (Murdiyarso et al. 2009) (Table 3).

Community Similarity Species similarity in this study was calculated according to Sørenson Coefficient (CCs) between these two communities. CCs value is started at 0 until 1 , where the 0 value shows that there is no similar species present in both community (Brower et al. 1997). While, 1 is the value showing all species are similar at both sites. From the value derived, both study sites had a very high in similarity that was $93 \%$. This value reflected that although the total stem density, species abundance, species dominance and species diversity were significantly different between the two sites, the species composition of these two forests is not affected by the different source of disturbance. Tree species in mangrove habitats are habitat specific plants that have morphological adaptations in order to survive in its extreme environment. Hence, despite of the types of disturbance, these limited numbers of mangrove species or also known as true mangroves (Duke 1992) are able to thrive in any mangrove forest communities.

Biomass Estimation The total AGB recorded at $46.45 \mathrm{t} / \mathrm{ha}$ (C5) and 173.09 (C7). At both study sites, Rhizophoraceae was the main contributor to the total biomass value estimated at C5 (37.24 t/ha) and C7 (160.93 t/ha). However, in C5, C.tagal with 22.41 t/ha or $60 \%$ of value showed the highest biomass and $R$. apiculata with a value of $111.75 \mathrm{t} /$ ha or $69.86 \%$ was the highest for C7 (Table 4 ). 
TABLE 3. Comparison of Shannon Diversity Index (H') among various study sites in South East Asia

\begin{tabular}{lccc}
\hline Location & Plot area (ha) & Diversity (H') & Source \\
\hline Langkawi, Kedah & 0.25 & 1.20 & Norhayati et al. 2005 \\
Matang FR, Perak & 0.06 & 0.82 & Norhayati et al. 2005 \\
Sungai Pulai FR, Johor & 0.10 & 1.43 & Jamaliah et al. 2003 \\
Sungai Belungkor FR, Johor & 0.10 & 1.63 & Intan Nordira et al. 2003 \\
Sungai Santi FR, Johor & 0.10 & 1.71 & Norhayati et al. 2005 \\
Sungai Balok FR, Pahang & 0.16 & 1.82 & Rozainah \& Mohamad 2006 \\
Trang, Thailand & 0.88 & $1.11-1.99$ & Sudtongkong \& Webb 2008 \\
Tanjung Putting National Park, Indonesia & & 3.29 & Murdiyarso et al. 2009 \\
Bahile FR, Palawan, Philippines & & 0.99 & Abino et al. 2014 \\
\hline
\end{tabular}

FR $=$ Forest Reserve

Even though $\mathrm{C} 5$ had a higher number of individuals compared to that of $\mathrm{C} 7$, the total AGB in $\mathrm{C} 7$ showed a higher biomass value than in $\mathrm{C} 5$. This was caused by the differences in DBH classes and the species occurrence in the respective study sites. C5 was covered by $97 \%$ of small trees (DBH class $1-9.99 \mathrm{~cm}$ ) out of 1,217 individuals that reflected a low total AGB value. The calculation of biomass for C. tagal that dominated C5 did not include the biomass of roots, as used for Rhizophora species, which contributes ca. $20 \%$ of the biomass of a tree. In C7, which display a homogenous distribution of the 390 individuals at all size classes, Rhizophora species contributed $75 \%$ (122.21 t/ha) of the total biomass, while C5 only had $34 \%$ or $12.79 \mathrm{t} / \mathrm{ha}$ ) contribution from this particular genus for each study sites. This situation explains what causes the abnormalities in the total AGB when compared to the number of individuals in both study sites.

Located adjacent to Pulau Langkawi, Satun, Thailand recorded a similar AGB value to this study of $92.24 \mathrm{t} / \mathrm{ha}$ (Sudtongkong \& Webb 2008). However, there were studies done in Thailand, that showed somewhat comparable AGB values, such as in Ranong, Trat, Phuket, Champhon, Phang-Nga and Southwest Thailand that range from 62 t/ha 299 t/ha (Alongi \& Dixon 2000; Christensen 1978;
Imai et al. 2006; Jachowski et al. 2013; Komiyama et al. 1987; Phongsuksawat 2002; Poungparn 2003; Tamai et al. 1986). The differences in AGB values were mostly caused by human disturbance. Most of the secondary forests showed low values than those of primary lowland forests. Disturbances not only lower the AGB values by their densities, but along with their tree DBH sizes (Jachowski et al.2013). On the other hand, anthropogenic disturbance doesn't necessarily lead to the decrease of AGB. By comparison, a highly disturbed mangrove forest, such as Matang Forest Reserved, Perak is intensively harvested for charcoal production and ranked as the most successful nursery ground for fish and prawns (Jamizan \& Chong 2017), has a high mean AGB value of 409 t/ha. Even though Matang mangrove is disturbed with big scale interferences, it is known as a high managed mangrove with good management plan that benefits both economical and ecological sustainability.

In the vicinity, biomass estimation using Clough and Scott (1989) equation from studies done by Nizam et al. (2005) and Norhayati and Latiff (2001) showed a similar value to this study at $117.85 \mathrm{t} / \mathrm{ha}$ and $115.07 \mathrm{t} /$ ha, respectively. While, another similar study by FaridahHanum et al. (2012) showed a similar value to this study,

TABLE 4. Above ground biomass of mangrove trees at compartment 5 and 7, Kisap Forest Reserve, Langkawi Island, Peninsular Malaysia using

\begin{tabular}{llcc}
\hline \multirow{2}{*}{ Family } & \multirow{2}{*}{ Species } & \multicolumn{2}{c}{ Biomass (tonne/ha) } \\
\cline { 3 - 4 } Rhizophoraceae & Bruguiera gymnorrhiza & 0.11 & C7 \\
& Bruguiera parviflora & 2.81 & 2.85 \\
& Ceriops tagal & 28.86 & 36.04 \\
& Rhizophora apiculata & 14.37 & 17.73 \\
& Rhizophora mucronata & 0.16 & 106.16 \\
Meliaceae & Xylocarpus granatum & 0.13 & 8.72 \\
& Xylocarpus moluccensis & & 0.77 \\
Avicenniaceae & Avicennia officinalis & 0.01 & 0.81 \\
& Total & 46.45 & 0.01 \\
& & & 173.09 \\
\hline
\end{tabular}


particularly to the C5, when using equation by Komiyama et al. (2005), that is $98.4 \mathrm{t} / \mathrm{ha}$. From these studies, the biomass values of Langkawi Island mangrove forests were far less than those in Matang mangrove forests, where the mean AGB was 409 t/ha (Putz \& Chan 1986). This situation is believed to have been caused by the DBH size of stands at the study sites chosen (Wan Juliana \& Nizam 2005). The study sites at Langkawi Island were in gap phase with a number of dead trees. Furthermore, the diameter size of trees at Matang mangrove forests were larger than those in Langkawi Island as the forests at Langkawi were in the regenerating stage (Figure 2), whereby almost $90 \%$ of individuals were in the smallest DBH class size, $1-9.9 \mathrm{~cm}$.

\section{CONCLUSION}

Naturally-disturbed forest has a homogeneous distribution of individuals at almost all size classes due to the bolt of lightning that caused the death of individuals randomly. Whereas, anthropogenically disturbed forest has more individuals in the small size classes or the juvenile stage as the result of harvesting activities that eliminated most of the big-sized trees. The remaining stands were those in the small size trees which did not attain the size to be harvested. The higher biomass of the naturally disturbed compared to the anthropogenically disturbed indicated that lower productivity of forest is expected once a forest is subjected to anthropogenic activities. This research is expected to facilitate further studies especially for long term monitoring.

\section{ACKNOWLEDGEMENTS}

The authors would like to thank the Langkawi District Forestry Office, Langkawi Development Authority (LADA), Persatuan Nelayan Kilim, Universiti Malaysia Terengganu and to those involved for their assistance and guidance throughout this study. The study was supported by UKM-AP-PLW-01/2009 and UKM-ST-06-FRGS-0247-2010 research grants.

\section{REFERENCES}

Abino, A.C., Castillo, J.A.A. \& Lee, Y.J. 2014. Assessment of species diversity, biomass and carbon sequestration potential of a natural mangrove stand in Samar, the Philippines. Forest Science and Technology 10(1): 2-8.

Aldrie, A. \& Latiff, A. 2006. Hutan Simpan Merbok, Kedah: Warisan Kepelbagaian Hutan Paya Bakau. Kuala Lumpur: Forestry Department of Peninsular Malaysia.

Alongi, D.M. \& Dixon, P. 2000. Mangrove primary production and above and below-ground biomass in Sawi Bay, Southern Thailand. Phuket Marine Biological Center Special Publication 22: 31-38.

Brower, J.E. \& Zar, J.H. 1977. Field and Laboratory Methods for General Ecology. Iowa: Wm. C. Brown Publisher.

Brower, S.E., Zarr, J.H. \& Ende, C.N. 1997. Field and Laboratory Methods for General Ecology. 4th ed. Boston: Mc Graw Hill.
Christensen, B. 1978. Biomass and productivity of Rhizophora apiculata Blume in a mangrove southern Thailand. Aquatic Botany 4: 43-52.

Clough, B.F. 2013. Continuing the Journey amongst Mangroves: ISME Mangrove Educational Book Series No. 1. Yokohama: International Society for Mangrove Ecosystems (ISME) and International Tropical Timber Organization (ITTO), Okinawa.

Clough, B.F. \& Scott, K. 1989. Allometric relationships for estimating above-ground biomass in six mangrove species. Forest Ecology and Management 27(2): 117-127.

Curtis, J.T. \& Macintosh, R.P. 1951. An upland continuum in the prairie-forest border region of Wisconsin. Ecology 32(3): 476-496.

Duke, N.C. 1992. Mangrove floristics and biogeography. In Tropical Mangrove Ecosystems. Coastal and Estuarine Studies Series, edited by Robertson, A.I. \& Alongi, D.M. Washington, D.C: American Geophysical Union. pp. 63100.

Faridah-Hanum, I., Kudus, K.A. \& Saari, N.S. 2012. Plant diversity and biomass of Marudu bay mangroves in Malaysia. Pakistan Journal of Botany 44(Suppl. 2): 151156.

Farnsworth,E.J. \& Ellison, A.M. 1997. The global conservation status of mangroves. Ambio 26(6): 328-334.

Forest Department of Peninsular Malaysia Annual Report (FDPM). 2014. Kuala Lumpur: Forestry Department of Peninsular Malaysia.

Feller, I.C. \& Mc Kee, K.L. 1999. Small gap creation in Belizean mangrove forests by a wood-boring insect 1 . Biotropica 31(4): 607-617.

Garrity, S.D., Levings, S.C. \& Burns, K.A. 1994. The Galeta oil spill. I. Long-term effects on the physical structure of the mangrove fringe. Estuarine, Coastal and Shelf Science 38(4): 327-348.

Giesen, W., Wulffraat, S., Zieren, M. \& Scholten, L. 2006. Mangrove guidebook for Southeast Asia, (part II). The Netherlands: FAO and Wetlands International 7. Bangkok: RAP.

Hammer, Ø., Harper, D.A.T. \& Ryan, P.D. PAST: 2001. Paleontological statistics software package for education and data analysis. Palaeontologia Electronica 4(1): 1-9.

Hase, H., Foelster, H. \& Lindheim, M. 1985. On the accuracy of estimating aboveground tree biomass in an evergreen forest near Manaus, Brazil: A simulation study. Biotropica 17(3): 191-195.

Imai, N., Takyu, M., Nakamura, Y. \& Nakamura, T. 2006. Gap formation and regeneration of tropical mangrove forests in Ranong, Thailand. Plant Ecology 186(1): 37-46.

Imbert, D., Rousteau, A. \& Scherrer, P. 2000. Ecology of mangrove growth and recovery in the Lesser Antilles: State of knowledge and basis for restoration projects. Restoration Ecology 8(3): 230-236.

Intan Nordira, A.K., Norhayati, A., Shukor, M.N. \& Wan Juliana, W.A. 2003. Komposisi spesies dan struktur hutan paya bakau di Hutan Simpan Belungkor, Johor. National Seminar Proceeding on Environmental Management. pp. 79-85.

Jachowski, N.R., Quak, M.S., Friess, D.A., Duangnamon, D., Webb, E.L \& Ziegler, A.D. 2013. Mangrove biomass estimation in Southwest Thailand using machine learning. Applied Geography 45: 311-321. 
Jamaliah, J., Norhayati, A., Nizam, M.S., Shukor, M.N. \& Wan Juliana, W.A. 2003. Komposisi dan biojisim spesies pokok paya bakau di Hutan Simpan Pulai, Johor. National Seminar Proceeding on Environmental Management. pp. 62-68.

Jamizan, A.R. \& Chong, V.C. 2017. Demersal fish and shrimp abundance in relation to mangrove hydrogeomorphological metrics. Sains Malaysiana 46(1): 9-19.

Japar Sidik, B. 1994. Mangrove plant resources in the ASEAN region volume I. Proceeding Third ASEAN-Australia Symposium on Living Coastal Resources. pp. 123-138.

Komiyama, A., Moriya, H., Prawiroatmodjo, S., Toma, T. \& Ogino, K. 1988. Primary productivity of mangrove forest. In Biological System of Mangroves: A Report of East Indonesian Mangrove Expedition, 1986, edited by Ogino, K. \& Chihara, M. Ehime: Ehime University. pp. 97-117.

Komiyama, A., Ogino, K., Aksornkoae, S. \& Sabhasri, S. 1987. Root biomass of a mangrove forest in southern Thailand. 1. Estimation by the trench method and the zonal structure of root biomass. Journal of Tropical Ecology 3: 97-108.

Komiyama, A., Poungparn, S. \& Kato, S. 2005. Common allometric equations for estimating the tree weight of mangroves. Journal of Tropical Ecology 21(04): 471-477.

Lugo, A.E. \& Snedaker, S.C. 1974. The ecology of mangroves. Annual Review of Ecology and Systematic 5: 39-64.

Macnae, W. 1968. A general account of the fauna and flora of mangrove swamps and forests in the Indo-West Pacific region. Advances in Marine Biology 6: 73-270.

Magurran, A.E. 1988. Ecological Diversity and its Assessment. Princeton: Princeton University Press.

Magurran, A.E. 2004. Measuring Biological Diversity. Oxford: Blackwell Publishing.

Murdiyarso, D., Donato, D., Kauffman, J.B., Kurnianto, S., Stidham, M. \& Kanninen, M. 2009. Carbon Storage in Mangrove and Peatland Ecosystems: A Preliminary Account from Plots in Indonesia (Working Paper 48). Bogor: Center for International Forestry Research (CIFOR).

Nizam, M.S., Fera Fizani, A.F., Hafizah, S., Norhayati, A. \& Latiff, A. 2005. Community structure and biomass estimation of trees at two mangrove forests in Pulau Langkawi. In Lembangan Kilim: Warisan Budaya dan Sumber Asli Langkawi, edited by Leman, M.S., Komoo, I., Latiff, A. \& Salleh, H. Bangi: LESTARI, UKM.pp. 243-249.

Norhayati, A., Nizam, M.S., Wan Juliana, W.A., Shukor, M.N., Fera Fizani, A.F., Hafizah, S., Sariah, H., Jamaliah, J., Intan Nordira, A.K. \& Latiff, A. 2005. Comparison of mangrove tree species composition at selected location in Peninsular Malaysia. In Sustainable Management of Matang Mangroves: 100 Years and Beyond, edited by Shaharuddin, M.I., Azahar, M., Razani, U., Kamaruzaman, A.B., Lim, K.I., Suhaili, R., Jalil, M.S. \& Latiff, A. Kuala Lumpur: Forestry Department Peninsular Malaysia. pp. 253-262.

Norhayati,A.\& Latiff,A. 2001. Biomass and species composition of a mangrove forest in Pulau Langkawi, Malaysia. Malaysian Applied Biology 30(1/2): 75-80.

Phongsuksawat, P. 2002. Determination of tree biomass in the mangrove habitat study area, Changwat Phangna. Master's thesis, Kasetsart University, Thailand (Unpublished).

Polidoro, B.A., Carpenter, K.E., Collins, L., Duke, N.C., Ellison, A.M., Ellison, J.C., Farnsworth, E.J., Fernando, E.S., Kathiresan, K., Koedam, N.E. \& Livingstone, S.R. 2010. The loss of species: Mangrove extinction risk and geographic areas of global concern. PloS One 5(4): 10095.
Poungparn, S. 2003. Common allometric relationships for estimating the biomass of mangrove forests. Doctoral dissertation, Gifu University, Japan (Unpublished).

Putz, F.E. \& Chan, H.T. 1986. Tree growth, dynamics, and productivity in a mature mangrove forest in Malaysia. Forest Ecology and Management 17(2): 211-230.

Rasheed, M.Z., Normaniza, O. \& Rozainah, M.Z. 2013. Physiological responses of Avicennia marina var. acutissima and Bruguiera parviflora under simulated rise in sea level. Sains Malaysiana 42(8): 1059-1064.

Rodin, L.E., Bazilevich, N.I. \& Fogg, G.E. 1967. Production and Mineral Cycling in Terrestrial Vegetation. London: Oliver and Boyd.

Rosli, R. \& Nor Atiqah, N. 2017. The effects of disturbance on the abundance and foraging behaviour of shorebirds and waterbirds in the tropical mudflat areas. Sains Malaysiana 46(3): 365-372.

Rozainah, M.Z. \& Mohamad, M.R. 2006. Mangrove forest species composition and density in Balok River, Pahang, Malaysia. Ecoprint 13: 23-28.

Sherman, R.E., Fahey, T.J. \& Battles, BB. 2000. Small-scale disturbance and regeneration dynamics in a neotropical mangrove forest. Journal of Ecology 88(1): 165-178.

Spalding, M., Kainuma, M. \& Collins, L. 2010. World Atlas of Mangroves. London: Routledge.

Soares, M.L.G. \& Schaeffer-Novelli, Y. 2005. Above-ground biomass of mangrove species. I. Analysis of models. Estuarine, Coastal and Shelf Science 65(1): 1-18.

Sudtongkong, C. \& Webb, E.L. 2008. Outcomes of state-vs. community-based mangrove management in southern Thailand. Ecology and Society 13(2): 27.

Tamai, S., Nakasuga, T., Tabuchi, R. \& Ogina, K. 1986. Standing biomass of mangrove forest in Southern Thailand. Journal of the Japanese Forestry Society 68(9): 384-388.

Tomlinson, P.B. 1986. The Botany of Mangroves. Cambridge: Cambridge University Press.

Wan Juliana, W.A. \& Nizam, M.S. 2005. Forest structure and above-ground biomass of two mangrove forest communities in Matang. In Sustainable Management of Matang Mangroves: 100 Years and Beyond. Forest Biodiversity Series 4, edited by Shaharuddin, M.I., Azahar, M., Razani, U., Kamaruzaman, A.B., Lim, K.I., Suhaili, R., Jalil, M.S. \& Latiff, A. Kuala Lumpur: Forestry Department of Peninsula Malaysia (FDPM). pp. 235-244.

Wan Juliana, W.A., Razali, M.S., Ehwan, N., Faizi, Z., Muhammad Azmil, A.R., Mohd.-Arrabe', A.B., Abdul Ghani, H., Norhayati, A. \& Latiff, A. 2014. Langkawi Geopark is home to rare mangrove flora. In Malaysian Naturalist, edited by Lakshmayya, G. Kuala Lumpur: Publication of The Malaysian Nature Society (MNS). pp. 50-53.

Wan Norilani Wan Ismail*, Wan Juliana Wan Ahmad \& A. Latiff School of Environmental and Natural Resource Science

Faculty of Science and Technology

Universiti Kebangsaan Malaysia

43600 UKM Bangi, Selangor Darul Ehsan

Malaysia 
Muhammad Razali Salam

Faculty of Science and Technology

Universiti Malaysia Terengganu

21000 Kuala Terengganu, Terengganu Darul Iman

Malaysia
*Corresponding author; email: wan_elani@yahoo.com

Received: 15 September 2017

Accepted: 14 December 2017 